Research Article

\title{
Effect of Recasted Material Addition on the Quality of Metal-Ceramic Bond: A Macro-, Micro-, and Nanostudy
}

\author{
Karolina Beer-Lech $\mathbb{D D}^{1}{ }^{1}$ Krzysztof Pałka, ${ }^{2}$ Anna Skic ${ }^{(D)},{ }^{1}$ Barbara Surowska, ${ }^{2}$ \\ and Krzysztof Gołacki ${ }^{1}$ \\ ${ }^{1}$ Department of Mechanical Engineering and Automation, Faculty of Production Engineering, \\ University of Life Sciences in Lublin, Głęboka Street 28, 20-612 Lublin, Poland \\ ${ }^{2}$ Department of Materials Engineering, Faculty of Mechanical Engineering, Lublin University of Technology, \\ Nadbystrzycka Street 36, 20-618 Lublin, Poland
}

Correspondence should be addressed to Anna Skic; anna.skic@up.lublin.pl

Received 15 December 2017; Revised 27 February 2018; Accepted 29 March 2018; Published 19 April 2018

Academic Editor: Patrice Berthod

Copyright (c) 2018 Karolina Beer-Lech et al. This is an open access article distributed under the Creative Commons Attribution License, which permits unrestricted use, distribution, and reproduction in any medium, provided the original work is properly cited.

\begin{abstract}
Using the recasted alloys in dental prosthetics could affect the quality of the metal-ceramic bond. However, scientists, alloys producers, and prosthetists are still of different opinions. The purpose of this study was to estimate the influence of recasting of the $\mathrm{NiCrMo}$ alloy on the metal-ceramic bond quality. The research was carried out on macro-, micro- and nanoscales using the threepoint bending test procedure and hardness tests as well as atomic force microscopy and SEM analyses. The SEM analyses showed good integrity of the metal-ceramic bond. The $\tau_{\mathrm{b}}$ index of all test samples was greater than $45 \mathrm{MPa}$. The highest values were recorded for the samples made of $50 \%$ and $100 \%$ of a brand new material. SEM analysis made after the bending test confirmed good metal-ceramic bond and exhibited adhesive-cohesive fracture. The largest hardness of metal plates was found for the samples containing $50 \%$ of the recycled material. Atomic force microscopy studies showed that the alloy containing $50 \%$ of the recycled material was characterized by the highest values of surface roughness parameters.
\end{abstract}

\section{Introduction}

The metal-ceramic dentures are still widely used due to good combination of their durability-high strength of metal substructures and esthetics of porcelain. They are also more economical than implants. Despite great popularity of precious metal alloys, the nonprecious $\mathrm{Co}-\mathrm{Cr}$ and $\mathrm{Ni}-\mathrm{Cr}$ ones are often used interchangeably because of their good mechanical properties and low costs.

Despite questioning the use of nickel alloys as biomaterials, due to the potential harmful effects on human tissues, nickelbase alloys are still widely used to manufacture the substructures of ceramic crowns and bridges. These alloys have larger elasticity modulus than the gold ones and thus thinner cross section of the alloy can be used to reduce destruction of the healthy tooth during crown manufacturing [1]. Moreover, the coefficient of thermal expansion of nickel alloys is compatible with that of thermal expansion of conventional ceramics that are used to produce dental veneers which provides a good metal-ceramic bond [2].

The final quality and reliability of partial dentures is influenced mainly by properties of denture and their design [3], the casting method $[4,5]$, and the use of already melted materials for casting its metal substructures [6]. The practice of using recasting materials is a very common way to reduce the cost of prosthetic components manufactured in dental laboratories. However, producer's and researcher's points of view are different in this case. Some manufacturers of dental alloys permit the use of once melted alloys but not less than the 50\% addition of the brand new material. They also require that the material must come from the same batch. Another group of manufacturers do not allow using remelted material (e.g., Heraeus Kulzer Co.) or do not provide any information on the use of dental alloys obtained from recycling. 
Recasting of $\mathrm{Ni}$-Cr dental alloys is the current topic in the literature. Researchers examine the effect of using recasted materials on properties such as chemical composition and precipitate formation and microstructure and its influence on mechanical properties, including testing of metal-ceramic bond strength.

Characterization of microstructure and metal-ceramic bond quality is generally made using several methods, for example, scanning electron microscopy (SEM) and atomic force microscopy (AFM). These methods have also been used to evaluate the surface morphology [7]. AFM provides three-dimensional detailed topographical images of surface roughness on a nanometer scale and has been used in dental research [8-14]. Roughness could be defined as a complex role of irregularities or little indentations that characterize a surface and influence on, inter alia, metalceramic bond quality [15]. Determination of surface roughness plays an important role in materials used for dental prostheses.

In spite of that the topic of recycling of nickel-based dental alloys is frequently discussed by research institutions, there is still no clear answer whether and how the use of the recycled material affects the quality of the metal-ceramic bond. There is also a lack of considering this issue from the perspective of different scales, which would allow a more complete identification of the causes of possible differences in the results of individual tests.

The purpose of this study was to investigate the influence of recycled material addition on the quality of the metalceramic bond (for the NiCrMo alloy), basis on tests in the micro- and nanoscales (surface properties) as well as in the macroscale (bond strength).

\section{Materials and Methods}

2.1. The Alloy and Casting Method. Specimens for all tests were made of the Heraenium NA alloy (Heraeus Kulzer $\mathrm{GmbH}$, Germany), whose chemical compositions were as follows (by weight): $\mathrm{Ni}-59.3 \% \mathrm{Cr}-24 \% \mathrm{Mo}-10 \% \mathrm{Fe}-1.5 \%$, $\mathrm{Mn}-1.5 \%$, and $\mathrm{Ta}-1.5 \% \mathrm{Si}-1.5 \% \mathrm{Nb}-1.0 \%$, according to the manufacturer's data [16]. The abovementioned alloy is used for casting crowns and bridges. The castings were made using a disposable alloy with a starting composition of $100 \%$, $50 \%$, and $0 \%$ of the brand new material made up to $100 \%$ by the recasted material according to Table 1. All materials came from the same batch. Casting and dental ceramic coating were carried out in a professional prosthetic laboratory according to the procedures applied to manufacture dental crowns and bridges. The vacuum pressure casting method (Nautilus, Bego Co.) and the ceramic crucibles (Nautilus) were used).

The specimens were purified from the investment material using first the coarse $(250 \mu \mathrm{m})$ and then the precision $(100 \mu \mathrm{m})$ abrasive cleaning (sandblasting). Sandblasting time for all samples was equal ( $15 \mathrm{~s}$ for each particle size). After sandblasting and cleaning the casting channels, from specimens "100" were used to manufacture the second and third groups of test specimens (foundry cones were not reused).
TABLE 1: Marking of the specimens.

\begin{tabular}{ll}
\hline $\begin{array}{l}\text { Specimen } \\
\text { marking }\end{array}$ & \multicolumn{1}{c}{ Composition } \\
\hline 100 & $\begin{array}{c}\text { Castings made of } 100 \% \text { of the brand new alloy } \\
\text { Castings made of } 50 \% \text { of the brand new alloy and } 50 \% \\
\text { of the already melted alloy comes from material } 100 \\
\text { Castings made of } 0 \% \text { of the brand new alloy (100\% of } \\
\text { the already melted alloy comes from material 100) }\end{array}$ \\
\hline
\end{tabular}

2.2. Samples and Porcelain Coating Method. Shapes and dimensions of the samples were in agreement with the ISO 9693 standard [17]. The samples had the shape of rectangular plates with dimensions of $25 \times 3 \times 0.5 \mathrm{~mm}$. They were cast from patterns cutout from wax sheets of $0.5 \mathrm{~mm}$ thick. To make foundry molds, the Bellavest $\mathrm{SH}$ investment bond (Bego Co.) was applied. The 10 minutes oxidation program was applied for all tested samples $(1223.15 \mathrm{~K})$.

The castings were coated with d.Sign porcelain (opaque, dentin, glaze, and Ivoclar Vivadent) into the rectangular area $(8 \times 3 \mathrm{~mm})$ in the center of one side of each metal specimen according to the manufacturer's specification. The samples were checked for dimensional correctness and the presence of potential external casting defects. Defected specimens were removed from the tests. The image of prepared specimens is presented in Figure 1(a).

2.3. SEM and AFM Structure Characterization. Characterization of specimen's surface was made by SEM and atomic force microscopy (NTEGRA Prima, NT-MDT, Moscow, Russia). Images of ceramic and metal surfaces were obtained using the scanning electron microscopy Nova NanoSEM 450 (FEI, Eindhoven, Netherlands) before and after the bending test. For the preparation for SEM observations sputtering of the samples with the gold layer of thickness about $7 \mathrm{~nm}$ was applied. Additionally, chemical composition analyses using the EDS method were carried out. Analyses were made using the Octane Pro EDS detector (EDAX) with the excitation voltage of $15 \mathrm{kV}$. Each specimen was analyzed three times, and the signal was detected from the area of about $600 \times 800 \mu \mathrm{m}$. The metal surface roughness parameters $\left(R_{\mathrm{q}}\right.$ is the root-mean-square deviation of the roughness profile, $R_{\mathrm{a}}$ is the arithmetical mean deviation of the roughness profile, $R_{\mathrm{p}}$ is the maximum peak height of the roughness profile, $R_{\mathrm{v}}$ is the maximum valley depth of the roughness profile, and $R_{\mathrm{z}}$ is the maximum height of roughness profile) were determined with NT-MDT software application [13]. In order to determine surface roughness of the alloy, the areas of $10 \times 10 \mu \mathrm{m}$ were scanned with $512 \times 512$ data points in the semicontact mode using a silicon cantilever (NSG30; NT-MDT) $125 \mu \mathrm{m}$ long, $4.0 \mu \mathrm{m}$ thick with a tip radius of $10 \mathrm{~nm}$, and the average resonance frequency of $300 \mathrm{kHz}$. The scan rate was $1 \mathrm{~Hz}$. Regions of interest were defined under the optical microscope. For each of the samples, three different areas, not closely located, were chosen. Obtained height images were used for determination of surface roughness parameters. All parameters were calculated for 15 lines per one image, and 

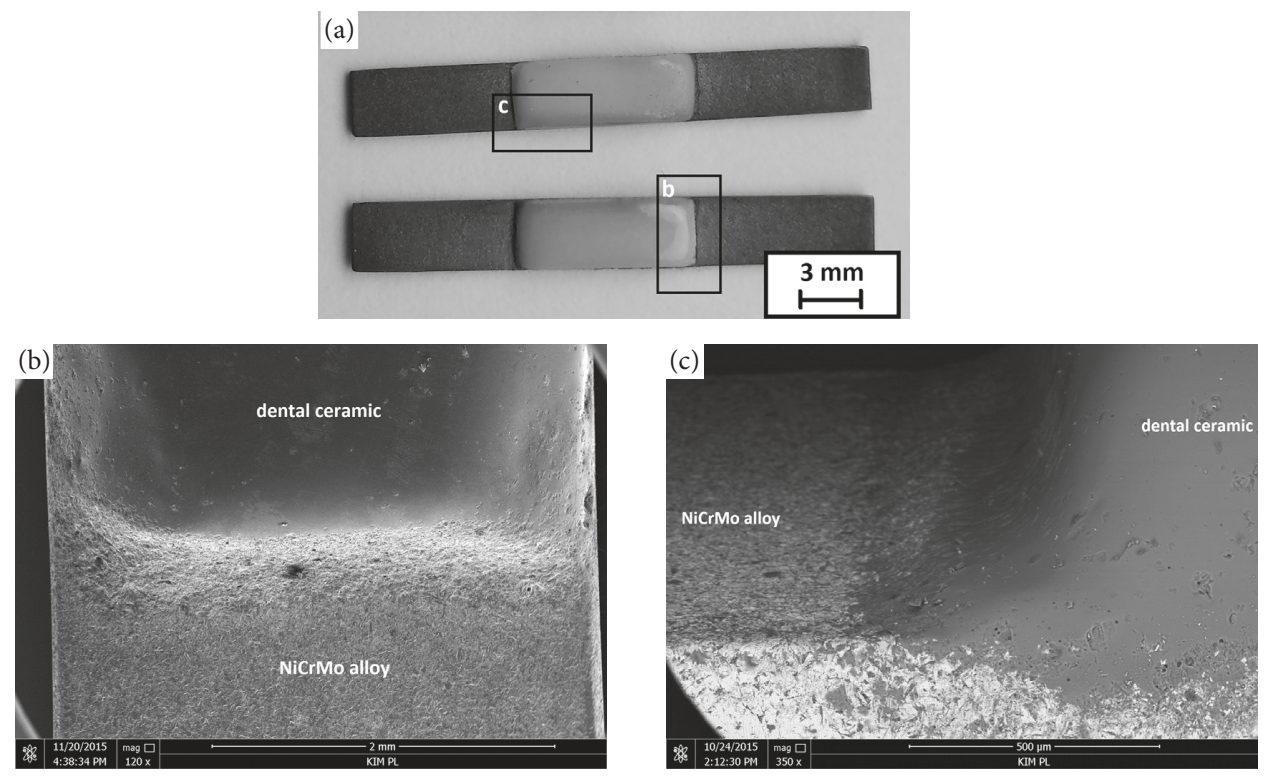

FIGURE 1: The exemplary groups (SEM images): (a) specimens used for the bending test; (b) metal-ceramic bond surface (view from the top); (c) metal-ceramic bond surface (lateral view) .

finally, a set of 540 data per experimental group was taken for further analysis.

The roughness parameters were checked for normal distribution and variances homogeneity (Levene's test). As the data were not normally distributed, the Kruskall-Wallis analysis of variance was applied to assess significant effects of recasted NiCrMo alloy addition on the determined parameters. Multiple comparisons of mean ranks were used to determine significant differences among the experimental groups (at the significance level of 0.05 ).

2.4. The Bending Test and Hardness Measurements. After the preliminary bending tests, using the power test analysis from the Statistica package, the number of samples needed for testing was determined. The test power was equal to 0.8 , the value of the significance level was $\alpha \leq 0.05$, and the measurement error was equal to $5 \%$.

Twelve samples were selected from each batch for the bending test, according to the ISO 9693-1:2012 standard [17]. The three-point bending test was performed on a Instron 8801 machine equipped with a $0.1 \mathrm{~N}$ accuracy load cell. The distance between the supports was $20 \mathrm{~mm}$, and the diameter of the rollers supporting the sample was $\varnothing 1 \mathrm{~mm}$. The test was conducted at the crosshead rate of $1.5 \mathrm{~mm} / \mathrm{min}$. The measurements were made up to a significant reduction in the value of the force appeared. This indicated the destruction of the metal-porcelain connection. The maximum recorded force was taken as the fracture force $\left(F_{\text {fail }}\right)$. The bond strength was calculated as the bonding compatibility index $\tau_{\mathrm{b}}$ [17] using the following equation:

$$
\tau_{b}=k_{1} \times F_{\text {fail }} .
$$

The fail force Ffail was multiplied by the coefficient $k_{1}$, which depends onthe thickness of the metal substrate, dM

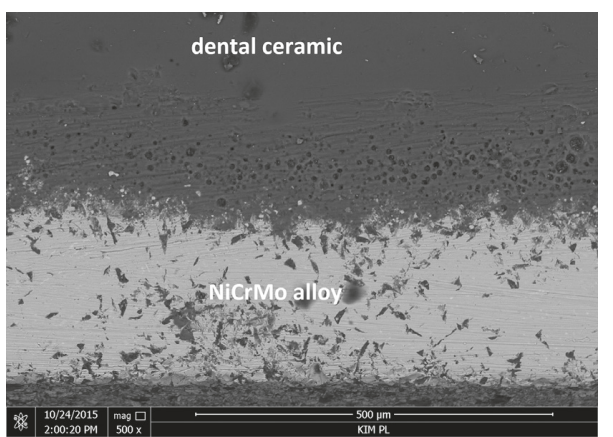

FIGURE 2: Lateral view of the metal-ceramic bond surface (specimen 100): porosity in dental porcelain (SEM image).

$d_{\mathrm{M}}((0.5 \pm 0.05) \mathrm{mm})$, and the Young's modulus, $E_{\mathrm{M}}$ and the Young's modulus value, EM, of the used metallic materials. Young's modulus was provided by the alloy manufacturer (for Heraenium $\mathrm{Na}$, the value was equal to $222 \mathrm{GPa}$ ). Hardness measurements (on the metal) were performed using the Vickers hardness tester FM-800 (Future-Tech Corp.). The applied load was $4.9 \mathrm{~N}$ which corresponds to the scale HV0.5. The duration of action of force was $10 \mathrm{~s}$.

\section{Results and Discussion}

Microstructural (SEM) analysis showed a good integrity of the metal-ceramic bonding in each case of tested specimens, regardless of the content of recycled material. Metal surface is characterized by a homogeneous structure, without any cracks and porosity (Figures $1(\mathrm{~b})$ and $1(\mathrm{c})$ ). On the ceramic surface, cracks were not observed either (Figure 1(b)). In a lateral view, the presence of microporosity in the ceramic layer was observed in most specimens (Figure 2). However, this fact cannot be 


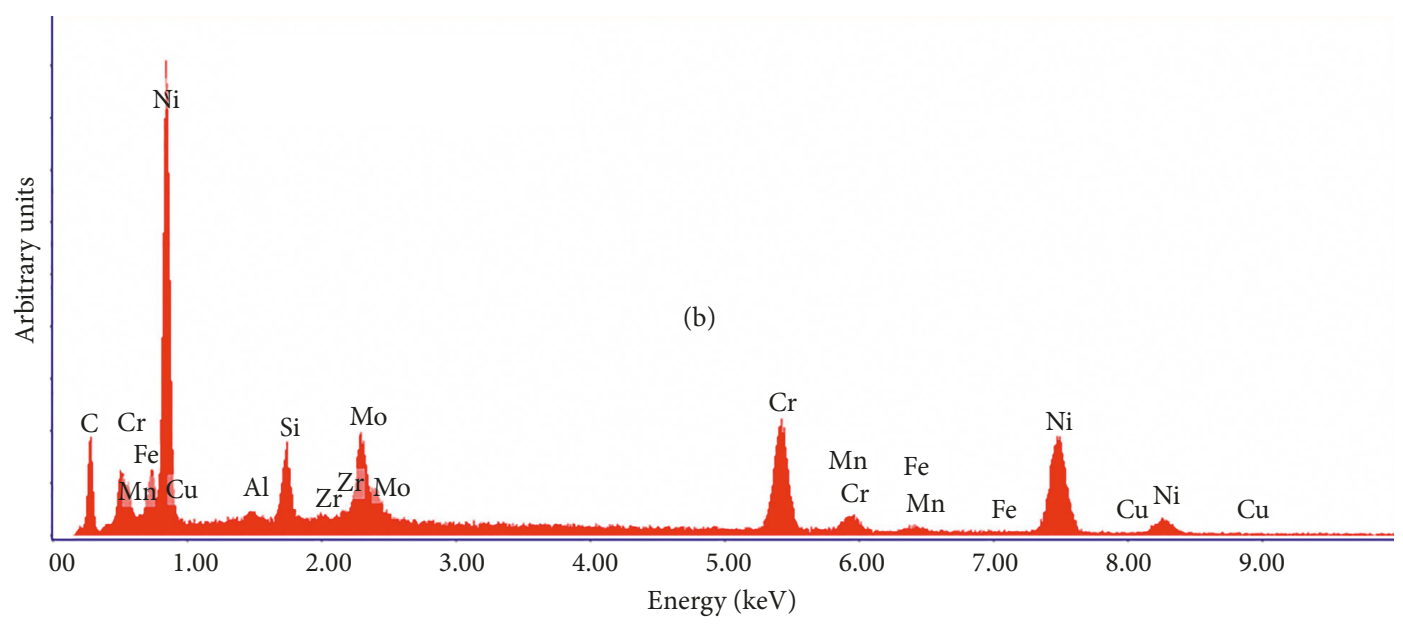

(a)

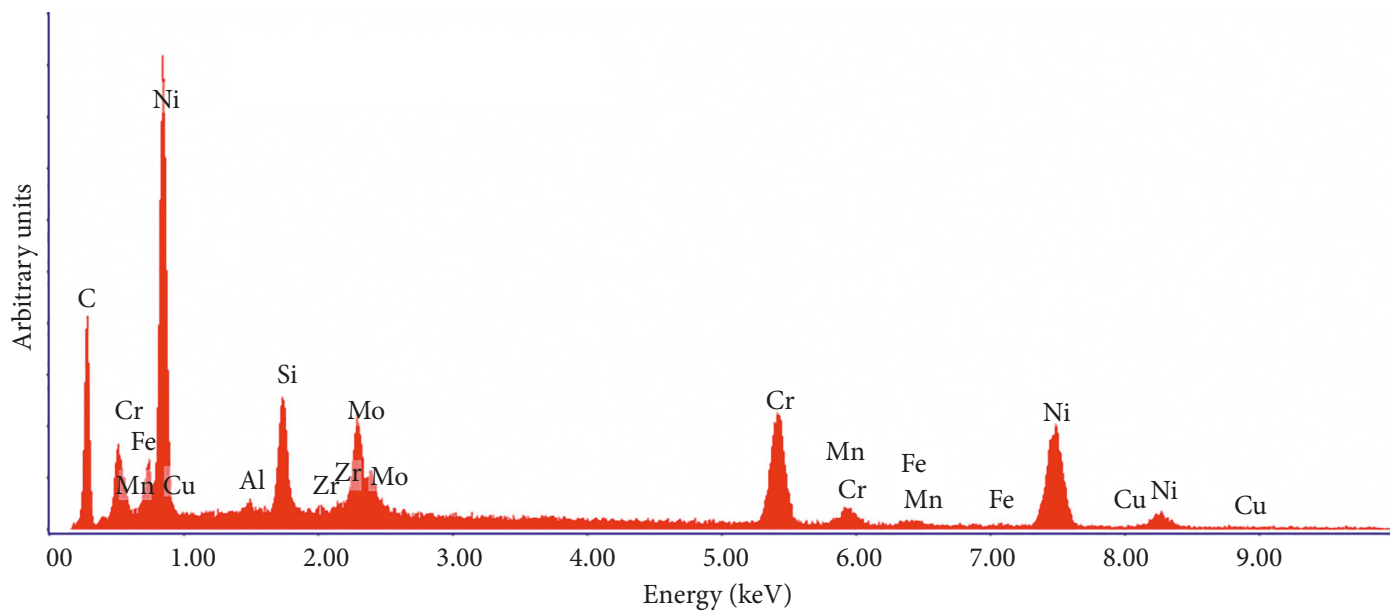

(b)

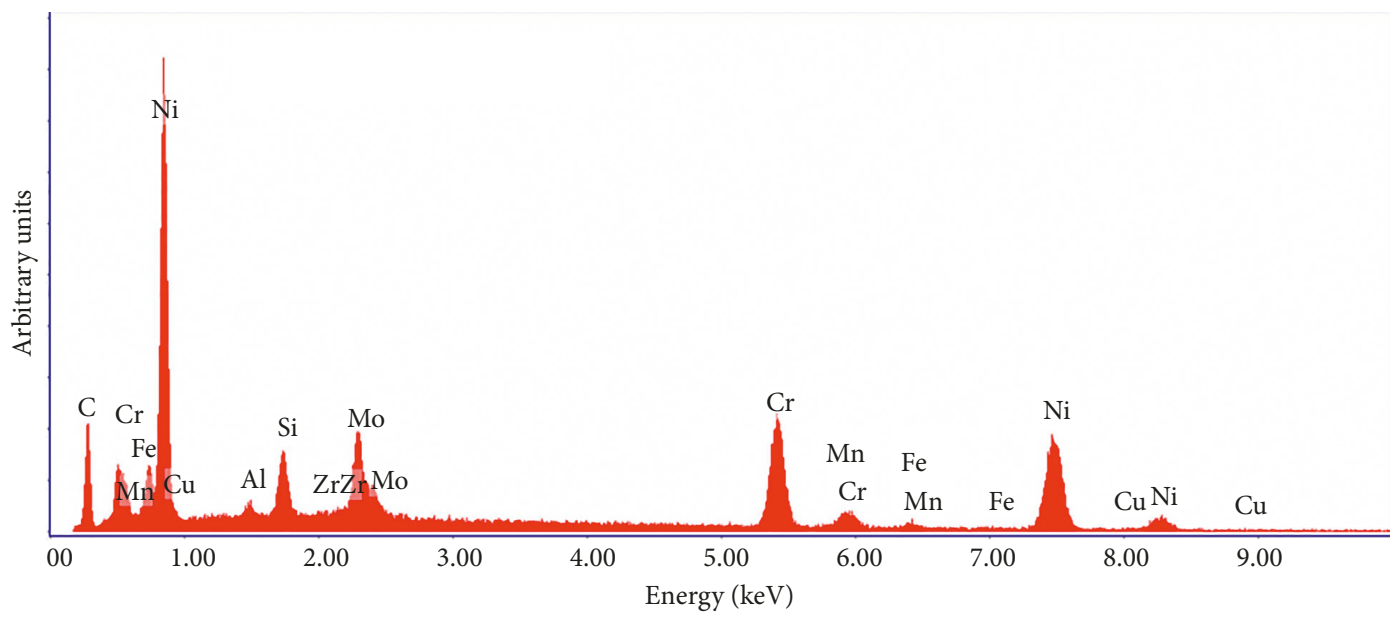

(c)

FIgURE 3: The results of chemical compositions analyses (EDS). (a) Sample 0. (b) Sample 50. (c) Sample 100.

associated with the content of the recycled material in metal castings. It would rather be due to precision of porcelain application on the sample surface. It is noteworthy that the precise of the application of the ceramic layer was the same in each case.
The results of chemical composition analyses (EDS) are presented in Figure 3 and Table 2 and contain the mean values. There were no significant differences observed in the amount of metallic elements for each type of the specimen. The differences were observed only for the carbon 
TABLE 2: The results of chemical composition analyses (\%) (EDS).

\begin{tabular}{lccccccccccc}
\hline Sample & $\mathrm{Al}$ & $\mathrm{Ta}$ & $\mathrm{Si}$ & $\mathrm{Zr}$ & $\mathrm{Nb}$ & $\mathrm{Mo}$ & $\mathrm{Cr}$ & $\mathrm{Mn}$ & $\mathrm{Fe}$ & $\mathrm{Cu}$ & $\mathrm{Ni}$ \\
\hline 0 & 1.06 & 0.71 & 2.68 & 0.08 & 0.74 & 8.91 & 23.36 & 1.08 & 1.47 & 0.48 & Balanced \\
50 & 0.86 & 0.62 & 2.43 & 0.40 & 0.68 & 8.54 & 24.73 & 1.46 & 1.49 & 0.46 & Balanced \\
100 & 0.61 & 1.27 & 2.67 & 0.13 & 0.78 & 9.15 & 24.27 & 1.04 & 1.54 & 0.53 & Balanced \\
\hline
\end{tabular}

TABLE 3: The mean values of surface roughness parameters (with SD values) and Kruskal-Wallis $H_{\mathrm{K}-\mathrm{w}}$ statistics results calculated for each parameter.

\begin{tabular}{|c|c|c|c|c|c|}
\hline Specimen & $R_{\mathrm{q}} \pm \mathrm{SD}(\mu \mathrm{m})$ & $R_{\mathrm{a}} \pm \mathrm{SD}(\mu \mathrm{m})$ & $R_{\mathrm{p}} \pm \mathrm{SD}(\mu \mathrm{m})$ & $R_{\mathrm{v}} \pm \mathrm{SD}(\mu \mathrm{m})$ & $R_{\mathrm{z}} \pm \mathrm{SD}(\mu \mathrm{m})$ \\
\hline 100 & $0.27 \pm 0.08^{\mathrm{a}}$ & $0.23 \pm 0.07^{\mathrm{a}}$ & $0.50 \pm 0.14^{\mathrm{a}}$ & $0.49 \pm 0.11^{\mathrm{a}}$ & $1.04 \pm 0.17^{\mathrm{a}}$ \\
\hline 50 & $0.38 \pm 0.13^{\mathrm{b}}$ & $0.27 \pm 0.10^{\mathrm{b}}$ & $0.68 \pm 0.27^{\mathrm{b}}$ & $0.80 \pm 0.19^{\mathrm{b}}$ & $1.37 \pm 0.39^{\mathrm{b}}$ \\
\hline 0 & $0.24 \pm 0.06^{\mathrm{a}}$ & $0.20 \pm 0.03^{\mathrm{a}}$ & $0.33 \pm 0.12^{c}$ & $0.34 \pm 0.05^{\mathrm{c}}$ & $0.75 \pm 0.15^{\mathrm{c}}$ \\
\hline Kruskal-Wallis $H$ test & $\begin{array}{c}H_{\mathrm{K}-\mathrm{W}}=27.42 \\
P<0.05\end{array}$ & $\begin{array}{c}H_{\mathrm{K}-\mathrm{W}}=12.41 \\
P<0.05\end{array}$ & $\begin{array}{c}H_{\mathrm{K}-\mathrm{W}}=25.99 \\
P<0.05\end{array}$ & $\begin{array}{c}H_{\mathrm{K}-\mathrm{W}}=77.27 \\
P<0.05\end{array}$ & $\begin{array}{c}H_{\mathrm{K}-\mathrm{W}}=49.71 \\
P<0.05\end{array}$ \\
\hline
\end{tabular}

$R_{\mathrm{q}}$, root-mean-square deviation of the roughness profile; $R_{\mathrm{a}}$, arithmetical mean deviation of the profile; $R_{\mathrm{p}}$, maximum roughness profile peak height; $R_{\mathrm{v}}$, maximum roughness profile valley depth; $R_{\mathrm{z}}$, ten-point height of irregularities; the mean values with dissimilar letters in the same column are significantly different at $P<0.05$. The letters $\mathrm{a}, \mathrm{b}$, and $\mathrm{c}$ indicate the existence of significant differences between the mean values of surface roughness parameters.

content with the highest peak obtained for specimen 50 (Figures 3(a)-3(c)). However, due to the EDS method limitations, the quantitative results were not presented.

The results of surface roughness analysis are shown in Table 3. The highest values of all calculated roughness parameters were observed for the specimens marked 50, whereas the 0 specimens were characterized by the smallest surface roughness (Table 3 ). This is also shown in Figure 4, which presents typical 2D and 3D topography images of investigated alloys. The statistical analysis showed significant effects of recasted NiCrMo alloy addition on $R_{\mathrm{q}}, R_{\mathrm{a}}, R_{\mathrm{p}}, R_{\mathrm{v}}$, and $R_{\mathrm{z}}$ parameters $(P<0.05)$. Despite the fact that the roughness was significantly the largest for specimen 50 , its average value was still small ( $R_{\mathrm{q}}$ below $\left.0.5 \mu \mathrm{m}\right)$. The low roughness is very important to avoid bacterial adhesion (size of about $1 \mu \mathrm{m}$ ) on the alloy surface when parts of the crown, not coated with the porcelain veneer, may remain in contact with the oral environment [18-21].

The $\tau_{\mathrm{b}}$ index of all tested samples, determined at the three-point bending test, was higher than $45 \mathrm{MPa}$ (Table 4). This indicates good connection of the pair metal-dental ceramic. According to Craig [22], a proper metal-ceramic bond exists when the $\tau_{\mathrm{b}}$ index reaches over $25 \mathrm{MPa}$. The highest values were recorded for the samples cast at $50 \%$ and $100 \%$ of the brand new material (approximately 48-49 $\mathrm{MPa}$ ). As the data did not meet the normal distribution conditions, the Kruskall-Wallis analysis of variance was applied to estimate significant effects of recasted NiCrMo alloy addition on the bonding compatibility index. The test did not show significant differences between values of $\tau_{\mathrm{b}}$ obtained for casting composed of $100 \%, 50 \%$, and $0 \%$ of the brand new material (Table 4).

The macro- and microscopic observations of the samples after the bending test are shown in Figure 5. The crack appearing between the dental ceramic and metal substrate is shown in Figure 5(a). It is visible only in the SEM imaging. The shape of the cracks takes the lamellar form with the angle between the crack and the metal substrate of about 10 degrees.
In almost all cases, the type of damage was mixed, adhesivecohesive. The next image (Figure 5(b)) shows the surface of the metal substrate after separation of the porcelain from the metal. The beginning of the cracking in the metal-ceramic joint was observed on the edge of the porcelain layer (maximum stresses). The presence of the thick residue ceramic layer at the ends of the layer area can be observed.

The hardness test showed that the highest values were found for the samples containing 50\% of the recycled material (Table 5). The lowest hardness values characterized castings made entirely from the recycled material, but the differences between samples 0 and 100 were not statistically significant. The ANOVA analysis demonstrated that there were statistically significant differences between the hardness of samples 100 and 50 as well 50 and 0 (Table 5).

An explanation of different hardness and surface roughness is required due to the same parameters of the sandblasting process. Sandblasting is an abrasive process which effectiveness and results are dependent on the mechanical properties of the material. In turn, the mechanical properties are related to, except chemical composition, the microstructure. The microstructure determines the susceptibility for abrasion. Materials exhibiting ductility and high strength are less susceptible for abrasion. Materials which are hard and brittle exhibit higher susceptibility for the erosion process. Microstructure of prosthetic alloys consists of solid solution of alloying elements in nickel with precipitations of intermetallic phases [3]. The amount of precipitates, related to materials used and the manufacturing process, corresponds with the hardness. The presence of precipitates causes brittleness and as a result higher roughness. It is confirmed by the appearance of the surface obtained from AFM (Figure 4), where steep slopes with sharp edges are visible.

The results are consistent with the similar study for the Remanium CS+ alloy (from Dentarum Co.) obtained by Walczak [23, 24], but they are not consistent with the Ucar's et al. research [25] for the RemaniumCSe alloy (the same manufacturer). These two alloys (Remanium CS+ and 


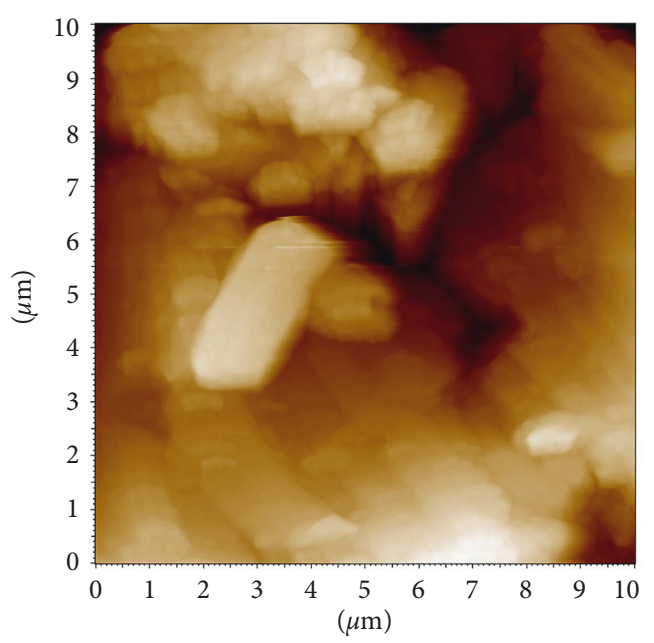

(a)

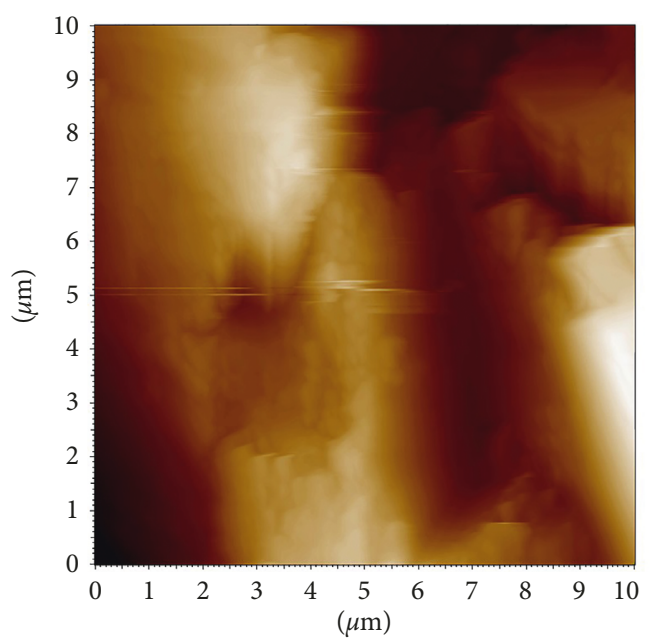

(c)

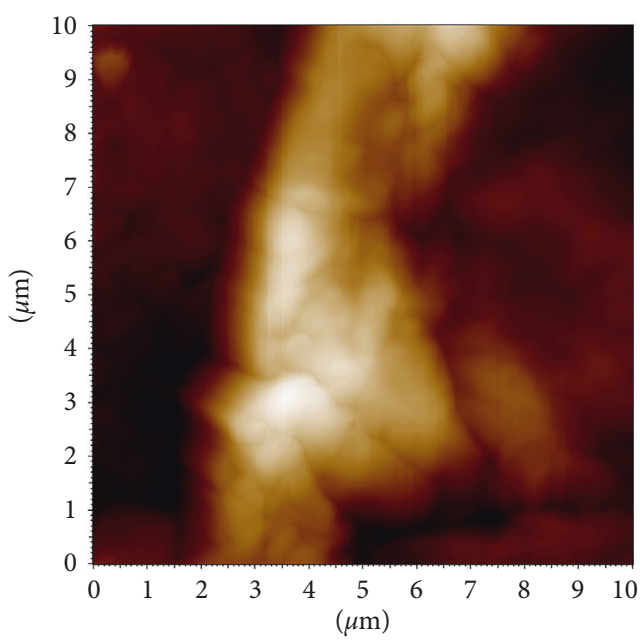

(e)

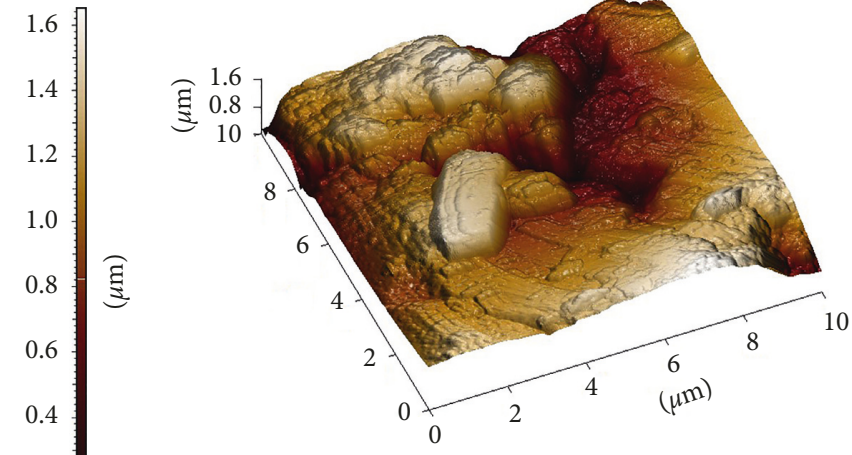

(b)
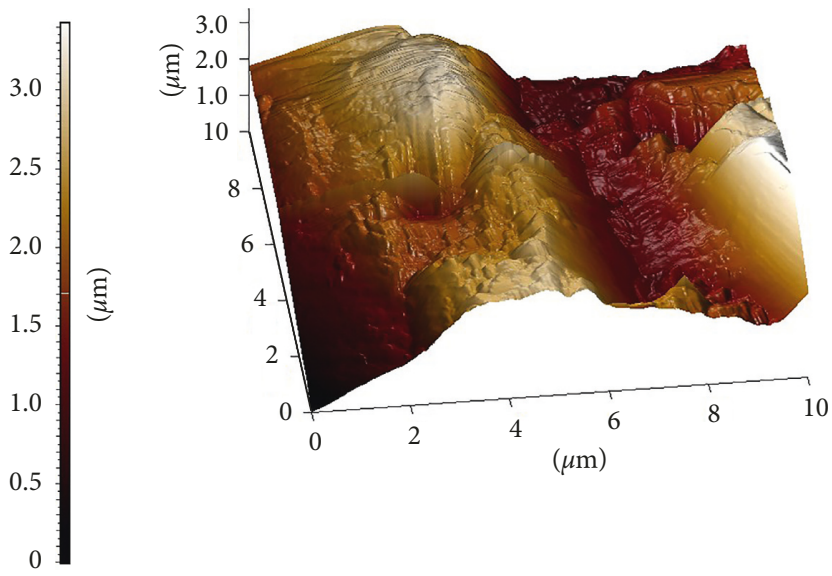

(d)

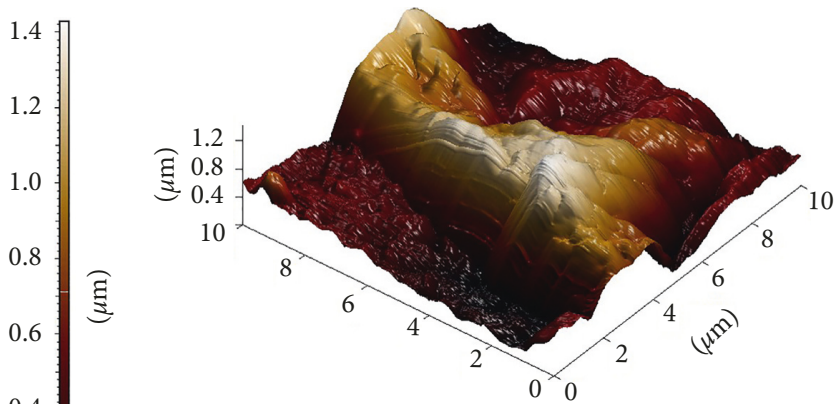

(f)

Figure 4: The AFM 2D (on the left) and 3D topography images (on the right) of specimen 100 (a, b), 50 (c, d), and 0 (e, f).

RemaniumCSe) have almost identical chemical composition. Ucar et al. [25] showed that the samples were evaluated visually (correctness of execution). However, in this study, the measurements of metal substrate hardness and the evaluation of surface roughness were not presented. Also, higher hardness values of metal framework cause greater 
TABLE 4: The mean values of the $\tau_{\mathrm{b}}$ index $( \pm \mathrm{SD})$ calculated for each group of specimens.

\begin{tabular}{lc}
\hline Specimen & $\tau_{\mathrm{b}}(\mathrm{MPa}) \pm \mathrm{SD}$ \\
\hline 100 & $48.43 \pm 3.59$ \\
50 & $49.21 \pm 5.43$ \\
0 & $46.48 \pm 6.58$ \\
Kruskal-Wallis $H$ test & $H_{\mathrm{K}-\mathrm{W}}=0.42 ; P=0.8$ \\
\hline
\end{tabular}
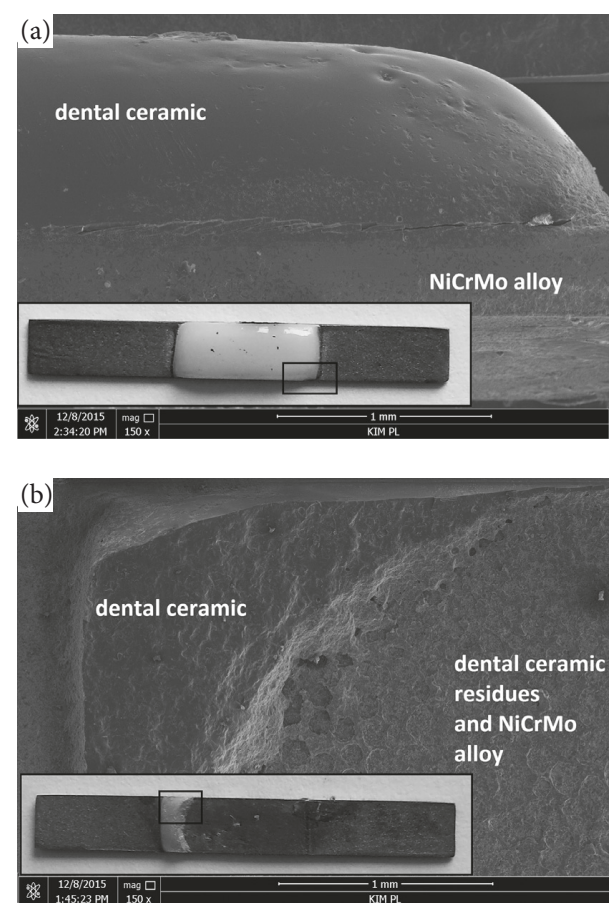

Figure 5: SEM images of the specimens after the three-point bending test: (a) specimen 100; (b) specimen 0 .

TABLE 5: The mean values of hardness $( \pm S D)$ for each group of specimens.

\begin{tabular}{lc}
\hline Specimen & HV $0.5 \pm \mathrm{SD}$ \\
\hline 100 & $253 \pm 9.4^{\mathrm{a}}$ \\
50 & $271 \pm 4.7^{\mathrm{b}}$ \\
0 & $262 \pm 6.5^{\mathrm{a}}$ \\
\hline
\end{tabular}

The mean values with dissimilar indices are significantly different at $P<0.05$. The letters $\mathrm{a}$ and $\mathrm{b}$ indicate the existence of significant differences between the mean values of hardness.

rigidity of the metal-ceramics system and result in quality differences of the metal-ceramic bond. A significant adverse effect of recasting $\mathrm{NiCr}$ alloys on the strength of the metalceramic bond and different points of view were presented by Madani et al. The authors reported the largest adhesion of dental porcelain on the castings made of the brand new material [26]. The study of multiple castings of nickelchromium alloys was also conducted by Mirkowić [27]. He noticed the occurrence of inconsiderable linear decrease in the elastic modulus up to the sixth generation of castings.

\section{Conclusions}

The study showed very good metal-porcelain bonding for all kinds of investigated castings. The best quality of the metal-ceramic bond was recorded for the material containing $50 \%$ of the brand new alloy; however, the differences between the groups were not statistically significant. The SEM analysis conducted after the bending test confirmed good metalceramic connection and exhibited the adhesive-cohesive fracture. The results of the bond strength are also confirmed by the microanalyses of the surface (SEM). Analysis of the surface morphology (AFM) revealed that the highest values of calculated roughness parameters were obtained for the material containing $50 \%$ of the brand new alloy. The metal-ceramic bond does not deteriorate quality when the material from recasting is used. Any small differences are due to those in hardness of the metal substrate and/or roughness. They do not affect the final quality of bonding. Further researches are planned to obtain required strength and corrosion resistance of the recasted material and improve the metal-ceramic bond.

\section{Conflicts of Interest}

The authors declare that they have no conflicts of interest.

\section{References}

[1] C. M. Wylie, R. M. Shelton, G. J. P. Fleming, and A. J. Davenport, "Corrosion of nickel-based dental casting alloys," Dental Materials, vol. 22, no. 6, pp. 714-723, 2007.

[2] J. W. McLean, The Science and Art of Dental Ceramics. The Nature of Dental Ceramics and Their Clinical Use, Quintessence Publishing, vol. 1, Chicago, IL, USA, 1979.

[3] K. Beer, K. Pałka, B. Surowska, and M. Walczak, "A quality assessment of casting dental prosthesis elements," Eksploatacja i Niezawodnosc-Maintenance and Reliability, vol. 15, no. 3, pp. 230-236, 2013.

[4] J. Bauer, J. F. Costa, C. N. Carvalho, R. H. Grande, A. D. Loguercio, and A. Reis, "Characterization of two Ni-Cr dental alloys and the influence of casting mode on mechanical properties," Journal of Prosthodontic Research, vol. 56, no. 4, pp. 264-271, 2012.

[5] K. Beer-Lech and B. Surowska, "Research on resistance to corrosive wear of dental CoCrMo alloy containing postproduction scrap," Eksploatacja i Niezawodnosc-Maintenance and Reliability, vol. 17, no. 1, pp. 90-94, 2015.

[6] A. S. Vaillant-Corroy, P. Corne, P. De March, S. Fleutot, and F. Cleymand, "Influence of recasting on the quality of dental alloys: a systematic review," Journal of Prosthetic Dentistry, vol. 114, no. 2, pp. 205-211, 2015.

[7] A. Casucci, E. Osorio, R. Osorio et al., "Influence of different surface treatments on surface zirconia frameworks," Journal of Dentistry, vol. 37, no. 11, pp. 891-897, 2009.

[8] A. Kakaboura, M. Fragouli, C. Rahiotis, and N. Silikas, "Evaluation of surface characteristics of dental composites using profilometry, scanning electron, atomic force microscopy and gloss-meter," Journal of Materials Science: Materials in Medicine, vol. 18, no. 1, pp. 155-163, 2007. 
[9] G. J. Lee, K. H. Park, Y. G. Park, and H. K. Park, "A quantitative AFM analysis of nano-scale surface roughness in various orthodontic brackets," Micron, vol. 41, no. 7, pp. 775-782, 2010.

[10] M. G. Subaşı and Ö. İnan, "Evaluation of the topographical surface changes and roughness of zirconia after different surface treatments," Lasers in Medical Science, vol. 27, no. 4, pp. 735-742, 2012.

[11] J. J. Roa, G. Oncins, J. Díaz, X. G. Capdevila, F. Sanz, and M. Segarra, "Study of the friction, adhesion and mechanical properties of single crystals, ceramics and ceramic coatings by AFM," Journal of the European Ceramic Society, vol. 31, no. 4, pp. 429-449, 2011.

[12] M. Vilotić, T. Lainović, D. Kakaš, L. Blažić, D. Marković, and A. Ivanišević, "Atomic force microscopy in metal forming and dental materials characterization," Journal of Plastics Technology, vol. 37, no. 2, pp. 173-187, 2012.

[13] I. Świetlicka, S. Muszyński, E. Tomaszewska et al., "Prenatally administered HMB modifies the enamel surface roughness in spiny mice offspring: an atomic force microscopy study," Archives of Oral Biology, vol. 70, pp. 24-31, 2016.

[14] I. M. Pelin, A. Piednoir, D. Machon, P. Farge, C. Pirat, and S. M. M. Ramos, "Adhesion forces between AFM tips and superficial dentin surfaces," Journal of Colloid and Interface Science, vol. 376, no. 1, pp. 262-268, 2012.

[15] G. Cortés-Sandoval, G. A. Martínez-Castañón, N. PatiñoMarín, P. R. Martínez-Rodríguez, and J. P. LoyolaRodríguez, "Surface roughness and hardness evaluation of some base metal alloys and denture base acrylics used for oral rehabilitation," Materials Letters, vol. 144, pp. 100-105, 2015.

[16] March 2018, http://kulzer.com/int2/int/dental_technician/ products_a_to_z/hera_1/NonPreciousMetalAlloysforCB.aspx.

[17] ISO 9693-1:2012, Dentistry-Compatibility Testing-Part 1: Metal-Ceramic Systems, ISO, Geneva, Switzerland, 2012.

[18] E. Alcamo, The Microbiology Coloring Book, Addison-Wesley, New York, NY, USA, 1995.

[19] B. Klaić, V. Svetličić, A. Čelebić et al., "Analysis of surface topography and surface roughness of CoCr alloy samples by atomic force microscopy," Acta Stomatologica Croatica, vol. 41, no. 4, pp. 306-314, 2007.

[20] S. Ţălu, S. Stach, B. Klaić, T. Mišić, J. Malina, and A. Čelebić, "Morphology of Co-Cr-Mo dental alloy surfaces polished by three different mechanical procedures," Microscopy Research and Technique, vol. 78, no. 9, pp. 831-839, 2015.

[21] K. Banaszek, W. Szymański, B. Pietrzyk, and L. Klimek, "Adhesion of E. coli bacteria cells to prosthodontic alloys surfaces modified by $\mathrm{TiO}_{2}$ sol-gel coatings," Advances in Materials Science and Engineering, vol. 2013, Article ID 179241, 6 pages, 2013.

[22] R. G. Craig, Restorative Dental Materials, J. M. Powers and R. L. Sakaguchi, Eds., pp. 453-465, Elsevier Inc, New York, NY, USA, 12th edition, 2006.

[23] M. Walczak, Influence of the Selected Technological Processes on Durability of Metal-Ceramic Systems Used in Dental Prosthetics, Lublin University of Technology, Lublin Poland, 2014, in Polish.

[24] M. Walczak, J. Caban, and K. Gałuszko, "Studies of remelted nickel-based alloy in a simulated chemical environment," Przemysl Chemiczny, vol. 96, no. 6, pp. 1329-1332, 2017.

[25] Y. Ucar, Z. Aksahin, and C. Kurtoglu, "Metal ceramic bond after multiple castings of base metal alloy," Journal of Prosthetic Dentistry, vol. 102, no. 3, pp. 165-171, 2009.
[26] A. S. Madani, S. R. Rokni, A. Mohammadi, and M. Bahrami, "The effect of recasting on bond strength between porcelain and base-metal alloys," Journal of Prosthodontics, vol. 20, pp. 190-194, 2011.

[27] N. Mirkowić, "Effect of recasting on the elastic modulus of metal-ceramic systems from nickel-chromium and cobaltchromium alloys," Vojnosanitetski Pregled, vol. 64, no. 7, pp. 469-473, 2007. 


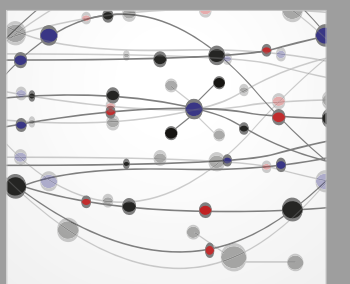

The Scientific World Journal
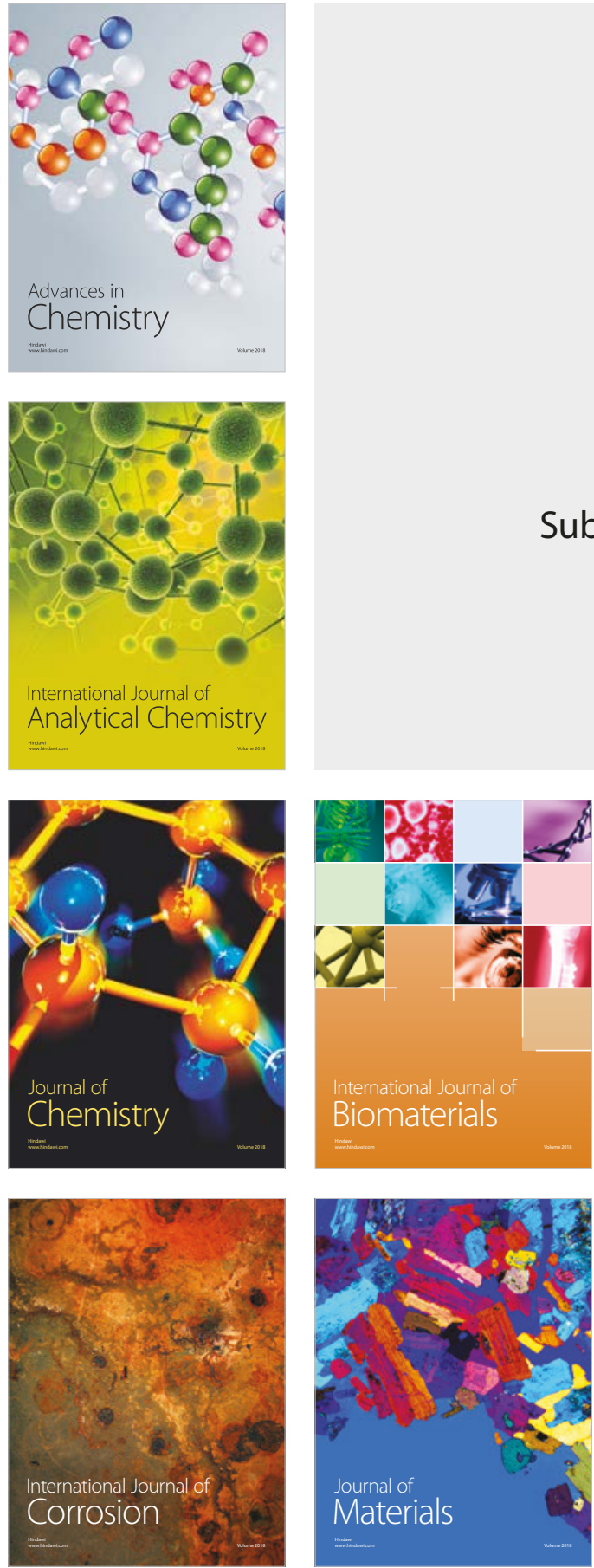

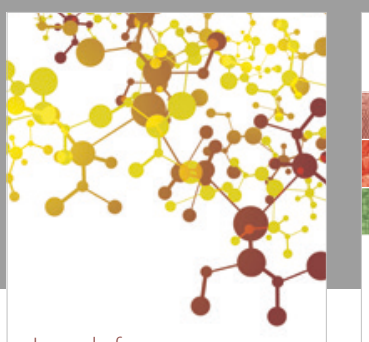

Journal of

Applied Chemistry
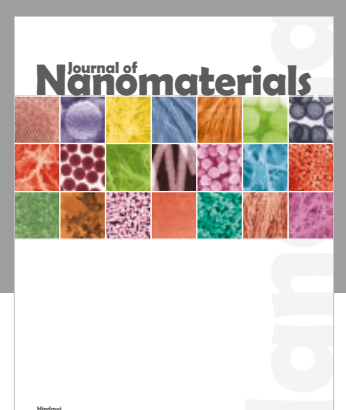

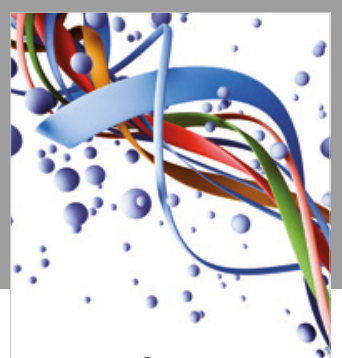

Scientifica

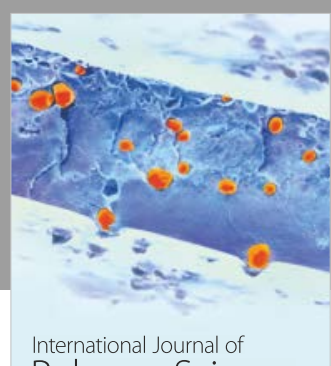

Polymer Science

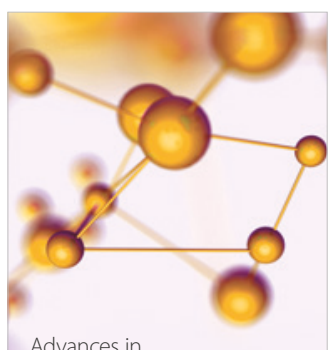

Physical Chemistry
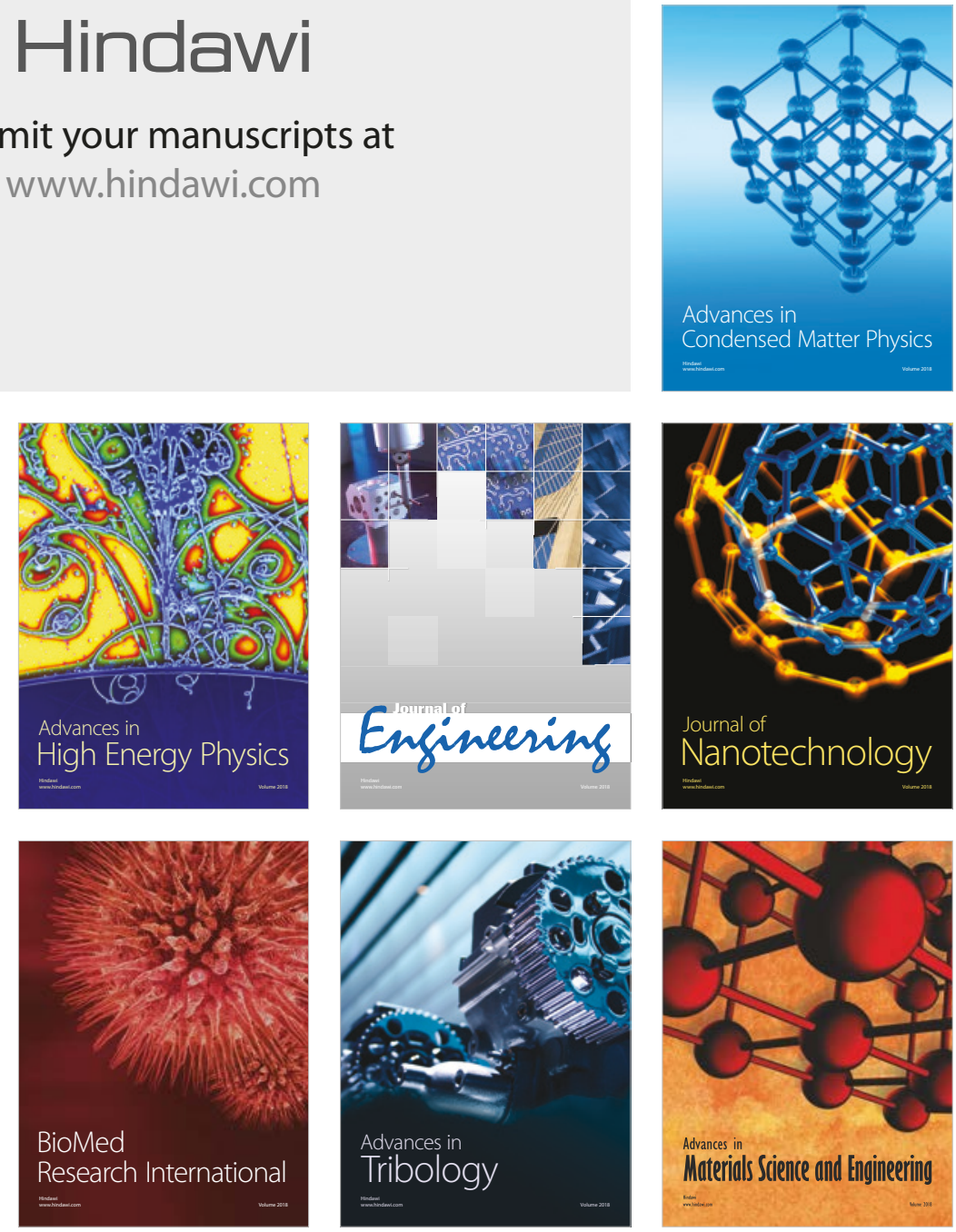